Article

\title{
Sensitivity Analysis of Envelope Design Parameters of Industrial Buildings with Natural Ventilation
}

\author{
Xiaojing Meng ${ }^{1,2, *}$, Beibei Wei ${ }^{2}$ and Yingni Zhai ${ }^{2,3}$ \\ 1 School of Resources Engineering, Xi'an University of Architecture and Technology, Xi'an 710055, China \\ 2 State Key Laboratory of Green Building in Western China, Xi'an University of Architecture and Technology, \\ Xi'an 710055, China; bbwei@xauat.edu.cn (B.W.); ynzhai@xauat.edu.cn (Y.Z.) \\ 3 School of Mechanical and Electrical Engineering, Xi'an University of Architecture and Technology, \\ Xi'an 710055, China \\ * Correspondence: meng0527@xauat.edu.cn; Tel.: +86-29-822-05869
}

Received: 16 November 2020; Accepted: 8 December 2020; Published: 9 December 2020

\begin{abstract}
It is beneficial for designers to identify the most important design parameters of building envelopes. This study undertook sensitivity analysis integrated with EnergyPlus to assess the impacts of envelope design parameters for naturally ventilated industrial buildings. Sensitivity coefficients of six envelope design parameters for different internal heat intensities were analyzed and compared for buildings in the city of Xi'an, located in the cold climate zone of China. Our results showed that the heat transfer coefficient of the roofs had the most significant impact on indoor temperature. The weights were $32.29 \%, 33.71 \%$ and $30.71 \%$, and the heat intensities were 5,10 and $15 \mathrm{~W} / \mathrm{m}^{3}$, respectively. The effect of the skylight-to-roof ratio was the second most sensitive. The impact of the solar absorptances of the walls and roof on the total number of hours was not sensitive. The results could be helpful for designers to efficiently form alternative design solutions in the design of new and retrofitting industrial buildings.
\end{abstract}

Keywords: sensitivity analysis; industrial buildings; envelope; design parameters; natural ventilation

\section{Introduction}

Industrial buildings are playing an important role in national construction and economic development [1]. The rapid development of industrialization has thrust China to the forefront of industrial construction in terms of scale, number of projects, and speed of construction. The floor area of industrial buildings that have been constructed in recent years in China [2] is depicted in Figure 1. The floor area of buildings constructed since 2011 has exceeded 500 million square meters per year, and the total area of existing industrial buildings is over 10 billion square meters in China. Such rapid development has drawn attention to the energy and environmental issues of industrial buildings. A large number of industrial buildings need to be retrofitted with the development of green buildings. There is great potential for energy efficiency in industrial buildings.

Various initiatives have been taken in China to improve energy efficiency in residential [3-5] and public buildings [6] by imposing tighter requirements on the thermal and energy performance of the building envelope. For example, standard JGJ 26-1986, “Energy conservation design standard for new heating in residential buildings", aimed to achieve energy savings of $30 \%$ for the heating of residential buildings in China, relative to those built in the 1980s. The 1995 revision of this standard raised the energy saving target to 50\%, and a subsequent revision in 2010, "Design standard for energy efficiency of residential buildings in severe cold and cold zones", raised it even higher to 65\% [3]. National standard GB 50189-2005, "Design standard for energy efficiency of public buildings", was intended to achieve energy savings of $50 \%$ for public buildings in China, compared with those 
built in the 1980s, while the 2015 revision could achieve energy savings of 20\% 23\% compared with the GB 50189-2005 standard [6]. The energy efficiency requirements for civil buildings has been increasing continuously in China. However, energy efficient design methods devised for residential and public buildings may be ill-suited to industrial buildings.

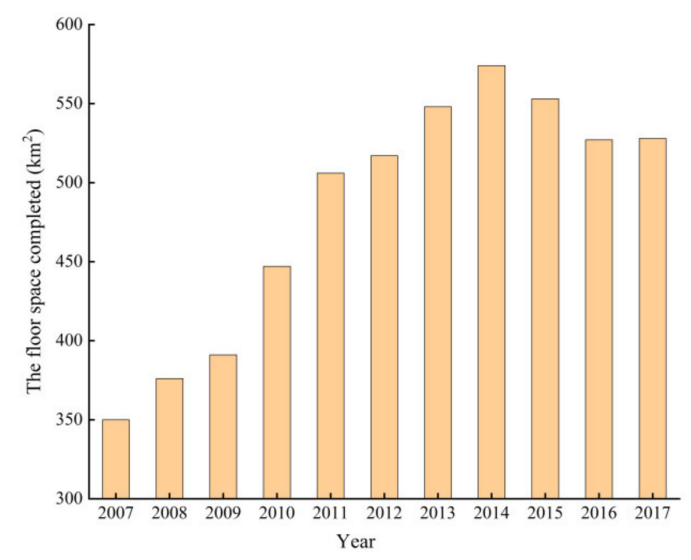

Figure 1. Floor space of industrial buildings in China.

The first national standard for the energy efficiency design of industrial buildings in China was introduced in 2017 [7], and the energy conservation of the industrial envelope is therefore becoming a major concern for the local government and designers. Industrial buildings are divided into two categories according to their mode of energy consumption [7]. For the first type of industrial building, energy consumption is mainly from heating in winter and air-conditioning in summer. The method of envelop design is similar to that used in residential and public buildings. For the second type of industrial buildings, ventilation energy comprises the main form of energy consumption. Natural ventilation is the main way of removing excess heat and pollutants from industrial buildings. However, many industrial buildings with natural ventilation have problems of overheating in summer and insufficient warming in winter. Wang and Meng [8,9] measured the thermal environment in a hot steel manufacturing plant located in $\mathrm{Xi}^{\prime}$ an, China, and observed that the average indoor temperature exceeded $35{ }^{\circ} \mathrm{C}$ in summer and was lower than $10{ }^{\circ} \mathrm{C}$ in winter. Moreover, excessive heat creates health risks and reduces work capacity and labor productivity [10]. For naturally ventilated industrial buildings, envelope design and ventilation design are the main methods available to improve the indoor environment. As a result, there is an urgent need for the development of optimal envelope designs of new industrial buildings and envelope retrofitting of existing industrial buildings in China.

The impacts of envelope design parameters on energy and thermal performance have been extensively studied. Increasing the thickness of insulation can directly improve thermal properties of buildings in order to decrease their heating and cooling energy consumption. Al-Khawaja, Alsayed and Huang et al. [11-13] analyzed the optimum insulation thickness. The window-to-wall ratio (WWR) and building shape coefficient are important factors in determining the design of energy efficiency buildings. The smaller these factors, the less heat loss occurs via the envelope and the less energy is consumed. Some researchers have conducted the optimization of WWR $[14,15]$ and shape coefficient [16-18]. Xu et al. [19] focused on the optimization of performance parameters design and the prediction of energy consumption for nearly zero energy buildings. The above research mainly concerns residential and public buildings. Therefore, the most important design parameters of the envelope are different to those of buildings with active heating and cooling.

The simplicity of building geometry allows the investigation of energy consumption for industrial building services to be limited to a few demand-side parameters. Optimized design solutions for industrial halls can be very sensitive to changes in process load [20]. Gourlis and Kovacic [21,22] have indicated that passive options (such as improvement of the building envelope and passive cooling strategies) had a large impact on the thermal environment of an industrial hall. However, 
increased insulation thicknesses are only cost-effective for industrial buildings with low internal heat intensities [23]. Previous studies have almost always concentrated on increasing thermal insulation, while other parameters have often been neglected. Sensitivity analysis makes it possible to identify the most important design parameters in relation to building performance. The sensitivities of design parameters provide guidelines for building designers on effective means of optimizing the thermal performance of envelope constructions [24]. Yu et al. [25] performed a sensitivity analysis of energy performance to assess the impacts of eight design parameters and identified the most important parameters for different WWR. A methodology of sensitivity analysis is presented and an application example is given for design of an office building in Denmark [26]. For naturally ventilated industrial buildings, comparatively high internal heat intensities make the industrial envelope design quite different from the civil building design.

The purpose of this paper is to identify the most important design parameters of industrial buildings with natural ventilation. In order to analyze the influence of envelope design parameters on the thermal environment, we perform sensitivity analysis of six envelope design parameters (heat transfer coefficients of the walls, heat transfer coefficients of the roof, heat transfer coefficients of the windows, solar absorptance of the walls, solar absorptance of the roof and skylight-to-roof ratio) for different internal heat intensities. A naturally ventilated industrial building with a constant shape coefficient and WWR are selected in Xi'an, a cold climate zone of China. Six envelope design parameters of the envelope are analyzed and compared. The results will be helpful for designers to efficiently generate alternative design solutions in the design of new and retrofitting industrial buildings.

\section{Method}

\subsection{Sensitivity Analysis}

Sensitivity analysis can quantitatively explain the effect of each parameter of a building envelope and identify important design parameters in order to improve the thermal environment and reduce energy use. Therefore, a sensitivity analysis method is chosen in this paper.

Sensitivity analysis determines the impact of a parameter by changing input and analyzing changes in output. It can be used to ascertain the degree of contribution of each input parameter to the generation of output variability and identify the most important and relatively insignificant parameters. The sensitivity coefficient $S_{i}$ of the design parameter $i$ can be defined as [24]:

$$
S_{i}=\frac{\left(\Delta L / L_{n}\right)}{\left(\Delta P_{i} / P_{i, n}\right)} \times 100 \%
$$

where $\Delta P_{i}$ is the change value of input parameter $i, \Delta P_{i}=P_{i}-P_{i, n} ; P_{i}$ is the value of the input parameter $i ; P_{i, n}$ is the value of the input parameter $i$ in the base case; $\Delta L$ is the output variation for the change of the input parameter, $\Delta L=L_{i}-L_{n} ; L_{i}$ is the output value corresponding to the input value $P_{i} ;$ and $L_{n}$ is the output value in the base case. Assuming that the sum of sensitivity coefficients of the six parameters is equal to 1, the weight of each input parameter on output variation can be calculated.

Sensitivity analysis can improve the efficiency of the design process and is helpful in the optimization of a building's envelope. The four basic steps in a sensitivity analysis include [26]: (1) define input and output variables, and assign the range and interval of each input parameter;

(2) assign the design parameters of the base case model, and calculate the output of the base case; (3) calculate the output distribution based on the variation of a given input parameter, and calculate the sensitivity coefficient according to Equation (1); and (4) assess the influence and relative importance of each design parameter on the output variables.

\subsection{Output Variables}

The output variables usually use the consumption of energy for heating and cooling. However, naturally ventilated industrial buildings do not utilize heating or cooling energy. Consequently, a new 
optimization objective is proposed based on indoor temperature. In Germany, the maximum acceptable workplace temperature is $26^{\circ} \mathrm{C}$, and the minimum acceptable temperature is $12^{\circ} \mathrm{C}$ [27]. Similarly, in the UK, the upper and lower limits are $27^{\circ} \mathrm{C}$ in summer and $13{ }^{\circ} \mathrm{C}$ for heavy work and $16{ }^{\circ} \mathrm{C}$ for light work in winter [28]. In China, the maximum workplace temperatures range from $24^{\circ} \mathrm{C}$ to $31^{\circ} \mathrm{C}$ based on the heat radiation intensity of work site, and minimum temperatures range from $12{ }^{\circ} \mathrm{C}$ to $18^{\circ} \mathrm{C}$ based on the intensity of work in industrial workplaces [29]. Workplace temperatures above $30{ }^{\circ} \mathrm{C}$ create health risks and reduce work efficiency [30]. Considering heavy work is common in industrial buildings, the maximum acceptable temperature is $30^{\circ} \mathrm{C}$ in summer and $14^{\circ} \mathrm{C}$ in winter. The output variables used in this study were the numbers of high-temperature $\left(>30^{\circ} \mathrm{C}\right)$ hours in summer (from 8.00 a.m. to 6.00 p.m. from 15 January-30 September), low-temperature $\left(<14{ }^{\circ} \mathrm{C}\right)$ hours in winter (from 8.00 a.m. to 6.00 p.m. from 15 December-1 March), and yearly total high- and low-temperature hours $\left(>30^{\circ} \mathrm{C}\right.$ or $\left.<14^{\circ} \mathrm{C}\right)$. The indoor temperature can be obtained by employing dynamic thermal simulations using EnergyPlus [31].

\subsection{Input Parameters}

It is essential to determine which input parameters are to be evaluated before performing sensitivity analysis. According to the standard GB 51245-2017 of China [7], the building shape coefficient and the WWR have a slight influence on the envelope's thermal performance in naturally ventilated industrial buildings. Li et al. [32] found that the variation ranges of the building shape coefficient and the WWR are small, from the investigation of 74 industrial buildings. Consequently, the shape coefficient and the WWR were not considered in this research. Six envelope design parameters (heat transfer coefficients of the walls, heat transfer coefficients of the roof, heat transfer coefficients of the windows, solar absorptance of the walls, solar absorptance of the roof and skylight-to-roof ratio) were chosen as input parameters.

Metal envelopes are usually used in industrial buildings. Common metal envelopes are listed in the standard GB 51245-2017 of China [7]. The heat transfer coefficients of walls of $0.42 \mathrm{~W} / \mathrm{m}^{2} \mathrm{~K}$, $0.55 \mathrm{~W} / \mathrm{m}^{2} \mathrm{~K}, 0.8 \mathrm{~W} / \mathrm{m}^{2} \mathrm{~K}, 1.23 \mathrm{~W} / \mathrm{m}^{2} \mathrm{~K}$ and $6.7 \mathrm{~W} / \mathrm{m}^{2} \mathrm{~K}$ are achieved and analyzed when the insulation thickness is $100 \mathrm{~mm}, 75 \mathrm{~mm}, 50 \mathrm{~mm}, 30 \mathrm{~mm}$ and $0 \mathrm{~mm}$, respectively. The heat transfer coefficients of roofs of $0.29 \mathrm{~W} / \mathrm{m}^{2} \mathrm{~K}, 0.36 \mathrm{~W} / \mathrm{m}^{2} \mathrm{~K}, 0.42 \mathrm{~W} / \mathrm{m}^{2} \mathrm{~K}, 0.55 \mathrm{~W} / \mathrm{m}^{2} \mathrm{~K}$ and $0.8 \mathrm{~W} / \mathrm{m}^{2} \mathrm{~K}$ are achieved and analyzed when the insulation thickness is $150 \mathrm{~mm}, 120 \mathrm{~mm}, 100 \mathrm{~mm}, 75 \mathrm{~mm}$ and $50 \mathrm{~mm}$, respectively. According to the investigation of industrial buildings in cold zones in China, the heat transfer coefficients of windows range from $1.8 \mathrm{~W} / \mathrm{m}^{2} \mathrm{~K}-3.6 \mathrm{~W} / \mathrm{m}^{2} \mathrm{~K}$ [32]. Five different window glasses were selected with the heat transfer coefficients of windows of $1.5 \mathrm{~W} / \mathrm{m}^{2} \mathrm{~K}, 2.0 \mathrm{~W} / \mathrm{m}^{2} \mathrm{~K}, 2.5 \mathrm{~W} / \mathrm{m}^{2} \mathrm{~K}, 3.0 \mathrm{~W} / \mathrm{m}^{2} \mathrm{~K}$ and $3.5 \mathrm{~W} / \mathrm{m}^{2} \mathrm{~K}$, respectively. The solar absorptance of common envelopes ranges from 0.5 to 0.9 [33]. According to the standard GB 51245-2017 of China [7], the skylight-to-roof ratio does not exceed 0.2. Table 1 shows the input parameters and their ranges and intervals.

Table 1. Design parameters and their ranges and intervals.

\begin{tabular}{ccc}
\hline Design Parameters & Range & Interval \\
\hline Heat transfer coefficient of walls $\left(\mathrm{W} / \mathrm{m}^{2} \mathrm{~K}\right)$ & $0.42-6.7$ & Unequal $^{1}$ \\
Heat transfer coefficient of roofs $\left(\mathrm{W} / \mathrm{m}^{2} \mathrm{~K}\right)$ & $0.29-0.8$ & Unequal $^{1}$ \\
Heat transfer coefficient of windows $\left(\mathrm{W} / \mathrm{m}^{2} \mathrm{~K}\right)$ & $1.5-3.5$ & 0.5 \\
Solar absorptance of walls & $0.5-0.9$ & 0.1 \\
Solar absorptance of roofs & $0.5-0.9$ & 0.1 \\
Skylight-to-roof ratio & $0-0.2$ & 0.05 \\
\hline 1 "Unequal” implies that the intervals of heat transfer coefficients of walls and roofs are not the same.
\end{tabular}

According to the input parameters and their ranges and intervals, there were five cases derived from changes of one parameter based on the base case model and 30 cases altogether from six input parameters. 


\section{Base Case Model}

According to the investigation [32] of envelope parameters in industrial buildings, $90 \%$ of buildings have a shape coefficient lower than 0.15 , and $50 \%$ of buildings have a value between 0.1 and 0.15 ; buildings with WWR lower than 0.3 account for $75 \%$ of buildings, and $52 \%$ of buildings have a WWR lower than 0.2. Consequently, a shape coefficient of 0.15 and WWR of 0.2 was selected as the base case model for this study. The base case model focuses on a typical industrial building (dimensions $150 \times 40 \times 12 \mathrm{~m}$ ) and is illustrated in Figure 2.

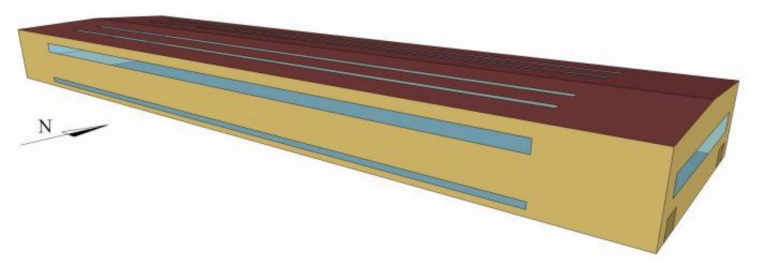

Figure 2. Base case model of an industrial building.

The industrial building was modeled using EnergyPlus as whole-building simulation software [31]. The thermal performance of envelopes in the base case model was set to comply with the standard GB 51245-2017 of China [7]. The skylight-to-roof ratio was set to 0.1. The heat transfer coefficients of the walls and roof were set to $0.8 \mathrm{~W} / \mathrm{m}^{2} \mathrm{~K}(0.6 \mathrm{~mm}$ steel plate, $50 \mathrm{~mm}$ glass cotton and $0.6 \mathrm{~mm}$ steel plate) and $0.55 \mathrm{~W} / \mathrm{m}^{2} \mathrm{~K}(0.6 \mathrm{~mm}$ steel plate, $75 \mathrm{~mm}$ glass cotton and $0.6 \mathrm{~mm}$ steel plate), respectively. The solar absorptances of the walls and roof were both set to 0.7 . The heat transfer coefficients of the windows and skylight were set to $3.0 \mathrm{~W} / \mathrm{m}^{2} \mathrm{~K}$ and $0.28 \mathrm{~W} / \mathrm{m}^{2} \mathrm{~K}$, respectively. The $3 \mathrm{D}$ base model of this case is illustrated in Figure 2.

In industrial buildings, the internal heat intensity associated with industrial facilities and manufacturing processes is taken into consideration. Internal heat gains from people and lightings are slight and can be ignored. Internal heat intensities are different for different manufacturing processes, which from $5-20 \mathrm{~W} / \mathrm{m}^{3}$. However, for industrial buildings with industrial furnaces, boilers, and gas turbine combustors, internal heat intensity may exceed $20 \mathrm{~W} / \mathrm{m}^{3}$ [34]. The internal heat intensities are set to 5,10 and $15 \mathrm{~W} / \mathrm{m}^{3}$ in this paper.

Natural ventilation rate is difficult to determine. Windows are operated by workers depending on the outdoor environment. In general, the windows stay open in summer and closed in winter. The skylight solves lighting problems, and thus it stays closed all year. In this paper, the infiltration and natural ventilation of the industrial building are assumed as constant air change rates, differing in summer and winter. In summer, the natural ventilation is calculated according to the design code for heating ventilation and air conditioning of industrial buildings [35]. In winter, the air infiltration rate is calculated according to the reference [36]. The air change rates are shown in Table 2.

Table 2. Air change rates.

\begin{tabular}{cccc}
\hline Internal Heat Intensity $\left(\mathbf{W} / \mathbf{m}^{\mathbf{3}}\right)$ & $\mathbf{5}$ & $\mathbf{1 0}$ & $\mathbf{1 5}$ \\
\hline Summer air change rate $\left(\mathrm{h}^{-1}\right)$ & 1.5 & 3 & 4.5 \\
Winter air change rate $\left(\mathrm{h}^{-1}\right)$ & 0.5 & 0.5 & 0.5 \\
\hline
\end{tabular}

To calculate the indoor temperature of an industrial building, the weather data should be set in advance in EnergyPlus. In this paper, $\mathrm{Xi}^{\prime}$ an, a typical city of cold climate zone in China, was used in the simulation. There are approximately 1646-2114 sunshine hours per year. The average winter temperatures range from $-1.2^{\circ} \mathrm{C}$ to $0{ }^{\circ} \mathrm{C}$ with a minimum temperature of $-4{ }^{\circ} \mathrm{C}$ in January, which is the coldest month of the year. During summer, this range is $26.3-26.6^{\circ} \mathrm{C}$ with a maximum temperature of $32{ }^{\circ} \mathrm{C}$ in July, which is the hottest month of the year. Typical meteorological year data of China [37] was used in the simulation process. 
For the base case model, the indoor and outdoor temperatures in summer (15 January-30 September) and winter (15 December-1 March) are shown in Figure 3, when the internal heat intensity is $5 \mathrm{~W} / \mathrm{m}^{3}$. The high-temperature, low-temperature and total hours for the base model for different heat intensities are shown in Figure 4. Heat intensity exerted a large effect on indoor temperature. For different heat intensities with different air change rates in summer, high-temperature hours slightly increased with increasing heat intensity. For different heat intensities with the same air change rate in winter, low-temperature hours decreased as heat intensity increased. The change law of total high- and low-temperature hours was the same as the low-temperature hours.
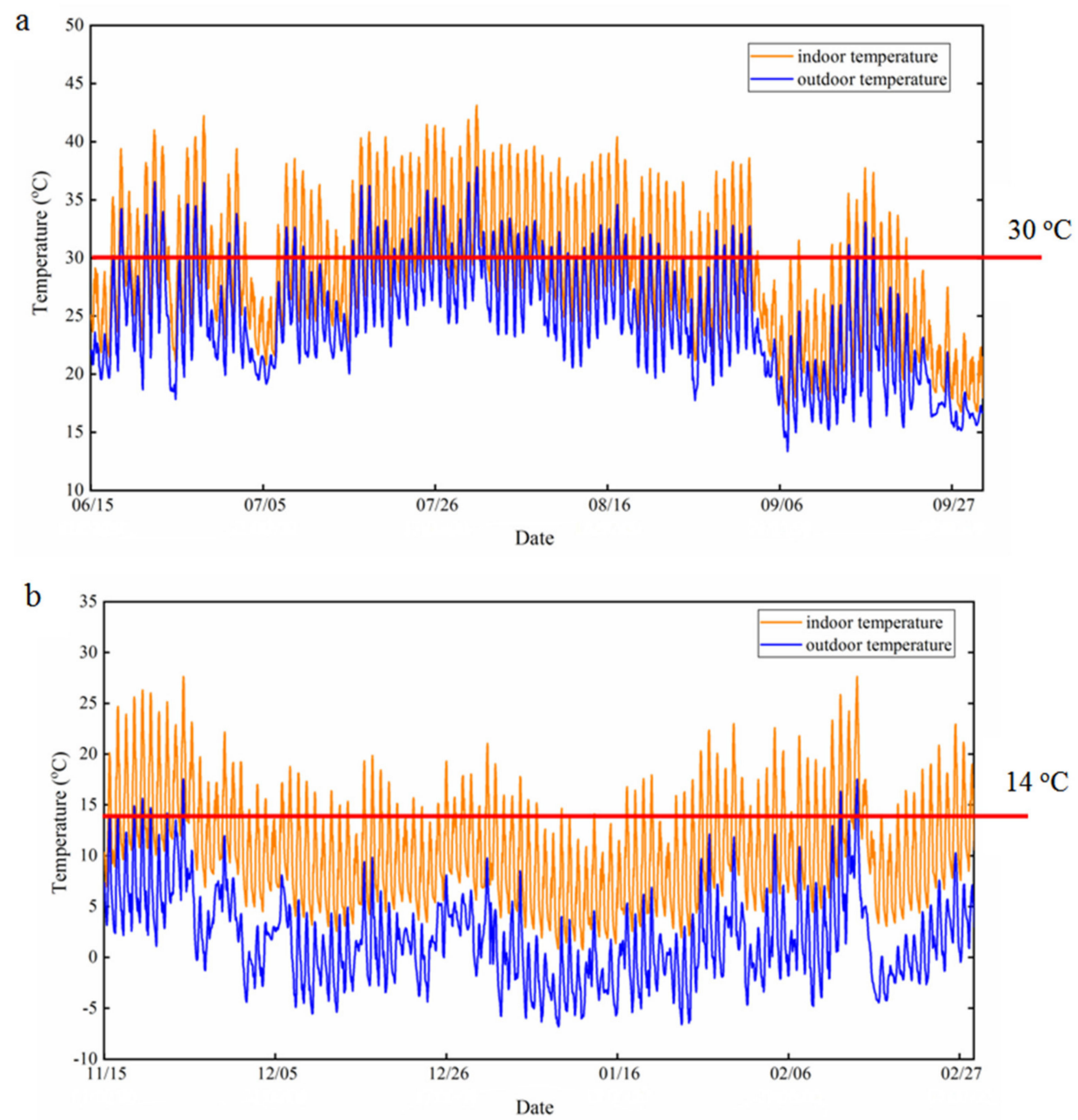

Figure 3. The indoor and outdoor temperatures in summer (a) and winter (b) for the base model, when the heat intensity is $5 \mathrm{~W} / \mathrm{m}^{3}$. 


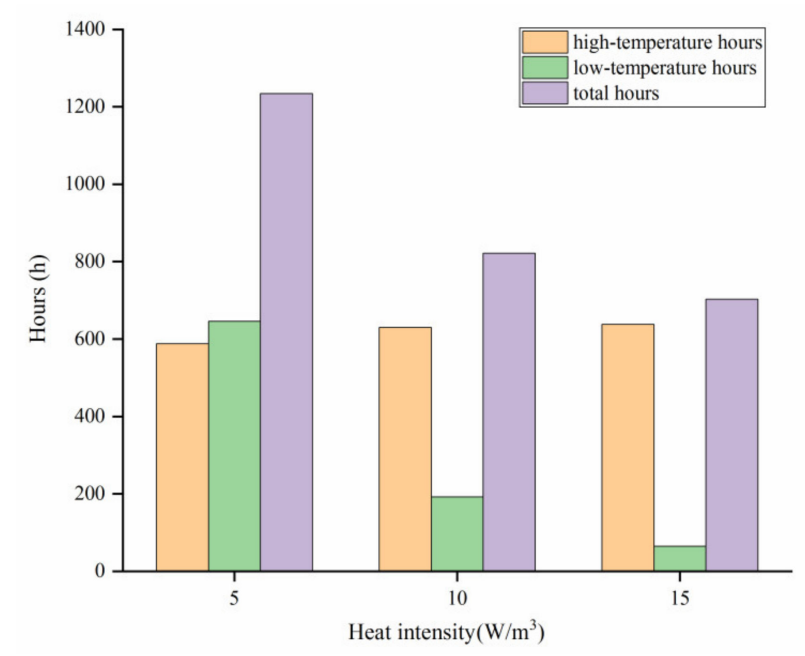

Figure 4. The high-temperature, low-temperature and total hours for the base model for different heat intensities.

\section{Results}

\subsection{Sensitivity Analysis of Design Parameters on High-Temperature Hours}

For the base case model, the high-temperature $\left(>30^{\circ} \mathrm{C}\right)$ hours were 588,630 and $638 \mathrm{~h}$ in the summer (from 8.00 a.m. to 6.00 p.m. from 15 January-30 September), and the heat intensities were 5, 10 and $15 \mathrm{~W} / \mathrm{m}^{3}$, respectively. Figure 5 displays the mean sensitivity coefficient of each design parameter for the number of high-temperature hours for different heat intensities. The sensitivity coefficients of the heat transfer coefficients of the envelope (walls, roof and windows) in high-temperature hours were negative, which indicated that the number of high-temperature hours decreased with increasing heat transfer coefficients in the envelope. In contrast, the sensitivity coefficients of the solar absorptances of the walls and the roof, and skylight-to-roof ratio, were positive. Therefore, as the solar absorptances of the walls, roof and skylight-to-roof ratio increased, the number of high-temperature hours increased. Thus, the values of the solar absorptances of the walls and roof, and skylight-to-roof ratio, should be lowered to reduce the number of high-temperature hours.

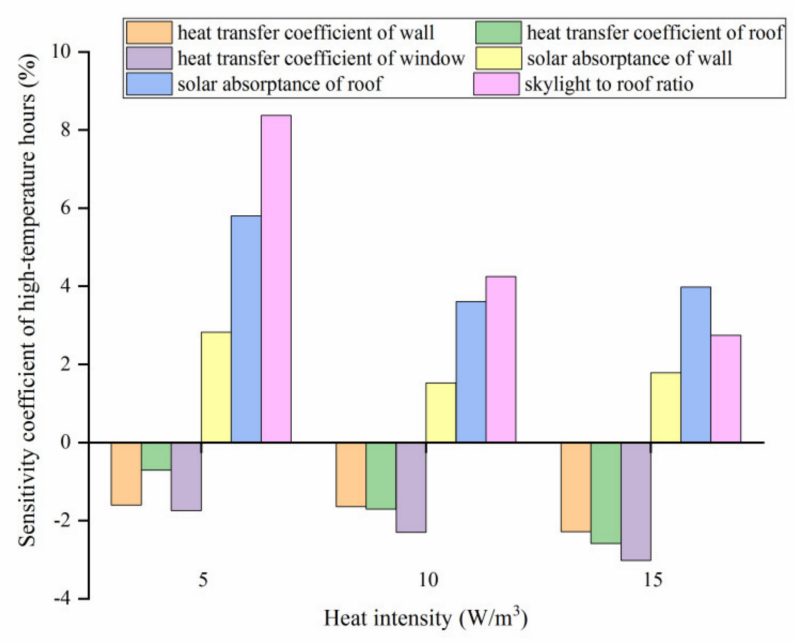

Figure 5. Sensitivity coefficient of high-temperature hours.

The higher the absolute value of a sensitivity coefficient, the greater the influence of the parameter is. Solar radiation is strong in summer, so design parameters (such as skylight-to-roof ratio and the solar absorptance of the roof and walls) related to solar radiation heat gain have a large impact 
on the number of high-temperature hours. The sensitivity coefficients of the parameters for the number of high-temperature hours were different for different heat intensities. Clearly, the sensitivity coefficients of the heat transfer coefficients of the envelope (walls, roof and windows) increased as heat intensity increased. This is because the indoor temperature was higher than the outdoor temperature in the summer, when the heat intensity was $5 \mathrm{~W} / \mathrm{m}^{3}$ (Figure 3a), and the temperature difference between indoor and outdoor air increased as heat intensity increased. The sensitivity coefficient of skylight-to-roof ratio decreased as heat intensity increased and ranged from $2.74 \%$ to $8.38 \%$.

When the heat intensity was 5 or $10 \mathrm{~W} / \mathrm{m}^{3}$, both the skylight-to-roof ratio and the solar absorptance of the roof were the most important parameters affecting the number of high-temperature hours. The weights of skylight-to-roof ratio were $39.77 \%$ and $28.23 \%$, and the weights of the solar absorptance of the roof were $27.55 \%$ and $24.02 \%$ for heat intensities of 5 and $10 \mathrm{~W} / \mathrm{m}^{3}$, respectively. The solar absorptance of the roof also played an important role in the number of high-temperature hours.

When the heat intensity was $15 \mathrm{~W} / \mathrm{m}^{3}$, the solar absorptance of roof, heat transfer coefficient of the window and skylight-to-roof ratio were important parameters affecting the number of high-temperature hours, and the weights were $24.28 \%, 18.42 \%$ and $16.74 \%$, respectively.

\subsection{Sensitivity Analysis of Design Parameters on Low Temperature Hours}

The low-temperature hours $\left(<14^{\circ} \mathrm{C}\right.$ ) in winter (from 8.00 a.m. to 6.00 p.m. from 15 th December-1st March) for the base case model were 646, 192 and $65 \mathrm{~h}$ for heat intensities of 5, 10 and $15 \mathrm{~W} / \mathrm{m}^{3}$, respectively. Figure 6 shows the mean sensitivity coefficients of the six design parameters for the number of low-temperature hours at different internal heat intensities. Results show that the sensitivity coefficients of the heat transfer coefficients the envelope (walls, roof and windows) for low-temperature hours were positive, while the sensitivity coefficients of the solar absorptances of the walls and roof were negative. As the heat transfer coefficients of envelope (walls, roof and windows) increased, heat loss through the envelope increased, which resulted in the number of low-temperature hours increasing. Conversely, as the solar absorptances of wall and roof increased, the heat gain from solar radiation increased, resulting in the number of low-temperature hours decreasing.

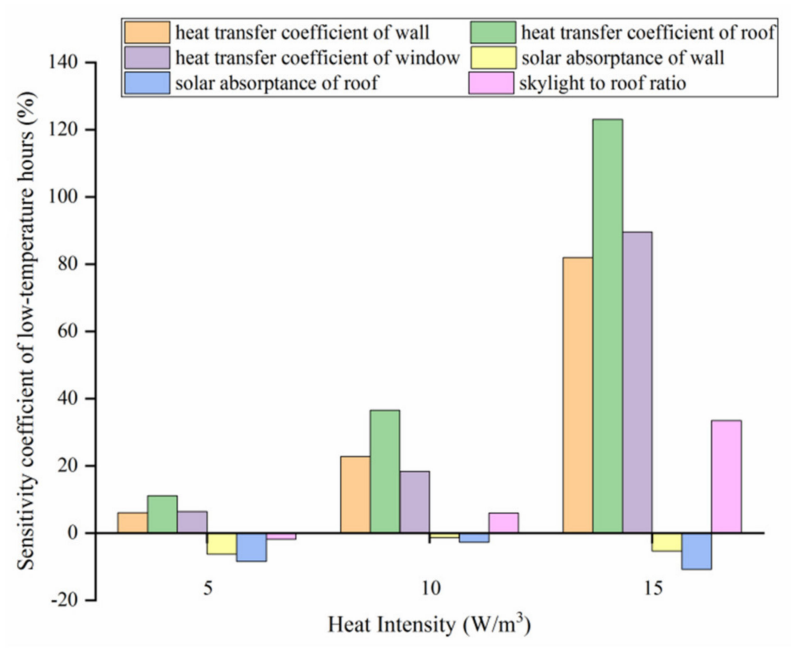

Figure 6. Sensitivity coefficient of low-temperature hours.

For industrial buildings, the roof area is usually large. The heat transfer coefficient of the roof was the most important parameter determining the number of low-temperature hours. The sensitivity coefficient of the heat transfer coefficient of the roof increased when the heat intensity increased, and ranged from $11.14 \%$ to $123.03 \%$. The reason for this was that the temperature difference between indoors and outdoors increased with heat intensity. Moreover, the number of low-temperature hours for the base case model decreased as the heat intensity increased. 
When the heat intensity was $5 \mathrm{~W} / \mathrm{m}^{3}$, the heat transfer coefficient and solar absorptance of the roof were the most vital factors for the number of high-temperature hours, and the weights were $27.75 \%$ and $20.93 \%$, respectively. When the heat intensities were 10 and $15 \mathrm{~W} / \mathrm{m}^{3}$, the heat transfer coefficients of the envelope (walls, roof and windows) were the most important parameters, and the weights were all more than $20 \%$ for each parameter. Whether the heat intensity was 5,10 or $15 \mathrm{~W} / \mathrm{m}^{3}$, the effect of skylight-to-roof ratio on the number of high-temperature hours was not sensitive.

\subsection{Sensitivity Analysis of Design Parameters on Total Hours}

For the base case model, the yearly total number of hours $\left(>30^{\circ} \mathrm{C}\right.$ or $\left.<14^{\circ} \mathrm{C}\right)$ was 1234,822 and $703 \mathrm{~h}$ for heat intensities of 5,10 and $15 \mathrm{~W} / \mathrm{m}^{3}$, respectively. Figure 7 displays the mean sensitivity coefficients of the six design parameters for the total number of hours at different internal heat intensities.

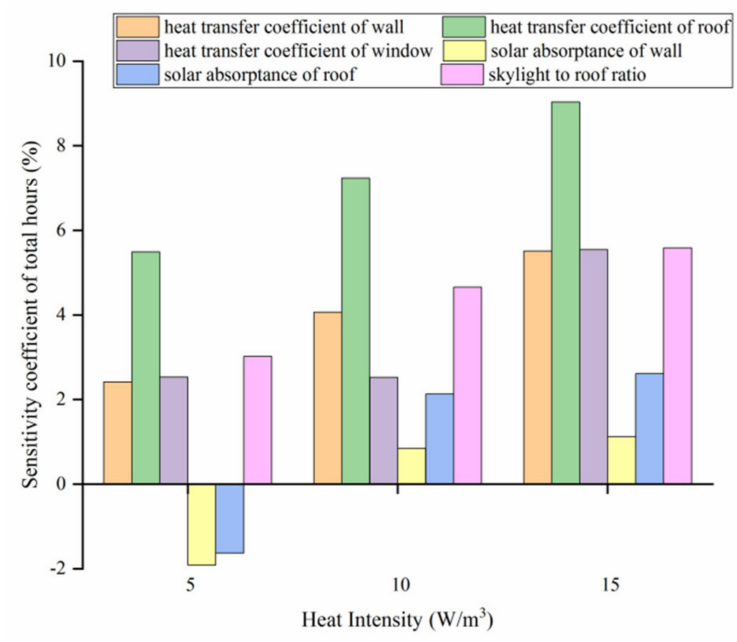

Figure 7. Sensitivity coefficient of total hours.

The importance of ranking the design parameters for different heat intensities is shown in Table 3 . It was observed that the heat transfer coefficient for the roof had the most obvious impact on the total number of hours at different internal heat intensities. When the heat intensities were 5,10 and $15 \mathrm{~W} / \mathrm{m}^{3}$, the sensitivity coefficients of the heat transfer coefficient of the roof were $5.49 \%, 7.23 \%$ and $9.03 \%$, and the weights of the heat transfer coefficient of roof were $32.29 \%, 33.71 \%$ and $30.71 \%$, respectively. Therefore, lowering the heat transfer coefficient of roof is the most efficient way to reduce the total number of hours. The effect of the skylight-to-roof ratio was in the second sensitive category. The weights of the skylight-to-roof ratio were $17.75 \%, 21.68 \%$ and $18.98 \%$ for heat intensities of 5 , 10 and $15 \mathrm{~W} / \mathrm{m}^{3}$, respectively. With a decrease in the skylight-to-roof ratio, the total number of hours were reduced by $0.81-3.27 \%$. For every decrease of 0.05 in the skylight-to-roof ratio, the heat intensities were 5,10 and $15 \mathrm{~W} / \mathrm{m}^{3}$. The impact of the solar absorptance of the walls and roof on the total number of hours was not sensitive at different internal heat intensities. The results give a general indication of which design parameters are of relative important to improving the thermal environment for naturally ventilated industrial buildings. 
Table 3. Importance ranking of the design parameters for different heat intensities.

\begin{tabular}{cccc}
\hline Design Parameters & $\mathbf{5 ~ W / \mathbf { m } ^ { \mathbf { 3 } }}$ & $\mathbf{1 0} \mathbf{W} / \mathbf{m}^{\mathbf{3}}$ & $\mathbf{1 5} \mathbf{~ W} / \mathbf{m}^{\mathbf{3}}$ \\
\hline Heat transfer coefficient of walls & 4 & 3 & 4 \\
Heat transfer coefficient of the roof & 1 & 1 & 1 \\
Heat transfer coefficient of windows & 3 & 4 & 3 \\
Solar absorptance of walls & 5 & 6 & 6 \\
Solar absorptance of the roof & 6 & 5 & 5 \\
Skylight-to-roof ratio & 2 & 2 & 2 \\
\hline
\end{tabular}

\section{Discussion}

The energy efficiency of residential and public buildings has attracted more attention than industrial buildings in the past few decades. With the development of industrial buildings, China is now the world's largest manufacturing country. Therefore, compared with residential and public buildings, industrial buildings have great potential for energy efficiency in China.

Yu et al. [25] found the heat transfer coefficient of walls and WWR are most sensitive to energy and thermal performance in residential buildings. In our study, the heat-transfer coefficient of the roof and skylight-to-roof ratio are the most sensitive to thermal performance in naturally ventilated industrial buildings. According to the standard GB 51245-2017 of China [7], the building shape coefficient and the WWR have a slight influence on the envelope's thermal performance in natural ventilated industrial buildings. Naturally ventilated industrial buildings with comparatively high internal heat intensities do not consume energy consumption, which makes the industrial envelope design quite different from the civil building design.

The envelope construction design is a part of a green buildings design. Švajlenka et al. [38] evaluated environmental construction systems in industrial construction by using the life cycle assessment method. They found that decisive impact on the overall environment is due to the production of building materials and their subsequent use. The use of wood constructions can ultimately improve the properties of the resulting structure in terms of cost saving, level of comfort for users, or sustainability in general [39]. Stefania et al. [40] looked at adaptive reuse in the context of industrial heritage. They defined an adaptive reuse project with positive repercussions for the community, the environment, and the local economy. Our work identified the most important design parameters for industrial buildings. Life cycle assessment and adaptive reuse should be considered in the development of green buildings.

This paper gives a general indication as to which design parameters are of relative importance to improving the thermal environment of naturally ventilated industrial buildings. The results can help designers in the early stages of envelope design for newly built industrial buildings and envelope retrofit of existing industrial buildings. In this paper, the indoor temperature used as a new optimization objective refers to the mean temperature. It is not appropriate for industrial buildings with local high-temperature heat sources. To simulate the thermal environment of industrial buildings, the interior space should be divided into several horizontal and vertical sub-zones to gain information about conditions at the occupants' height and in the different areas of the building. However, heat distribution in horizontal and vertical zones is complicated and worth investigating in the future.

\section{Conclusions}

The aim of this work was to identify the important design parameters of envelopes for naturally ventilated industrial buildings. The effects of envelope design parameters on high-temperature hours in summer, low-temperature hours in winter, and yearly total high-and low-temperature hours were examined using sensitivity analysis. The most important design parameters were identified. The heat transfer coefficient of roof had the most obvious impact at different internal heat intensities, and the weight was more than $30 \%$. The effect of skylight-to-roof ratio was the second most sensitive. The impact of solar absorptances of the walls and roof on the total number of hours was not sensitive for different 
indoor heat intensities. These results could be helpful for designers to efficiently generate alternative design solutions for the design of new and retrofitting industrial buildings with natural ventilation.

Author Contributions: X.M. and B.W. designed and performed the research and the paper; B.W. contributed the method and data analysis; X.M. wrote the paper; Y.Z. reviewed and edited the paper. All authors have read and agreed to the published version of the manuscript.

Funding: This research project was funded by the National Key R\&D Program of China (Grant No. 2018YFC0705300). Acknowledgments: The authors thank the National Key R\&D Program of China (Grant No. 2018YFC0705300).

Conflicts of Interest: The authors declare no conflict of interest.

\section{References}

1. Wang, Y.; Cao, Y.; Meng, X. Energy efficiency of industrial buildings. Indoor Built Environ. 2019, 28, $293-297$. [CrossRef]

2. Wang, Y. Energy Efficiency of Industrial Buildings, 1st ed.; Architecture and Building Press: Beijing, China, 2018.

3. JGJ 26-2010. Design Standard for Energy Efficiency of Residential Buildings in Severe Cold and Cold Zones; China Architecture and Building Press: Beijing, China, 2010.

4. JGJ 134-2010. Design Standard for Energy Efficiency of Residential Buildings in Hot Summer and Cold Winter Zone; China Architecture and Building Press: Beijing, China, 2010.

5. JGJ 75-2012. Design Standard for Energy Efficiency of Residential Buildings in Hot Summer and Warm Winter Zone; China Architecture and Building Press: Beijing, China, 2012.

6. GB 50189-2015. Design Standard for Energy Efficiency of Public Buildings; China Architecture and Building Press: Beijing, China, 2015.

7. GB 51245-2017. Unified Standard for Energy Efficiency Design of Industrial Buildings; China Planning Press: Beijing, China, 2017.

8. Wang, Y.; Gao, J.; Xing, X.; Liu, Y.; Meng, X. Measurement and evaluation of indoor thermal environment in a naturally ventilated industrial building with high temperature heat sources. Build. Environ. 2016, 96, 35-45. [CrossRef]

9. Meng, X.; Wang, Y.; Xing, X.; Liu, T. Characteristics analysis of convection and radiation in industrial plants with high temperature heat source. J. HV AC 2018, 46, 36-39.

10. Parsons, K. Human Thermal Environments: The Effects of Hot, Moderate and Cold Environments on Human Health, Comfort and Performance, 3rd ed.; CRC Press: Boca Raton, FL, USA, 2014.

11. Al-Khawaja, M. Determination and selecting the optimum thickness of insulation for buildings in hot countries by accounting for solar radiation. Appl. Eng. 2004, 24, 2601-2610. [CrossRef]

12. Ucar, A. Thermoeconomic analysis method for optimization of insulation thickness for the four different climatic regions of Turkey. Energy 2010, 35, 1854-1864. [CrossRef]

13. Huang, J.; Lv, H.; Gao, T.; Feng, W.; Chen, Y.; Zhou, T. Thermal properties optimization of envelope in energy-saving renovation of existing public buildings. Energy Build. 2014, 75, 504-510. [CrossRef]

14. Su, X.; Zhang, X. Environmental performance optimization of window-Wall ratio for different window type in hot summer and cold winter zone in China based on life cycle assessment. Energy Build. 2010, 42, 198-202. [CrossRef]

15. Goia, F. Search for the optimal window-to-wall ratio in office buildings in different European climates and the implications on total energy saving potential. Sol. Energy 2016, 132, 467-492. [CrossRef]

16. Inanici, M.; Demirbilek, F. Thermal performance optimization of building aspect ratio and south window size in five cities having different climatic characteristics of Turkey. Build. Environ. 2000, 35, 41-52. [CrossRef]

17. Lin, M.; Pan, Y.; Long, W. Influence of building shape coefficient on energy consumption of office buildings in hot-summer-and-cold-winter area of china. Build. Energy Effic. 2015, 10, 728-735.

18. McKeen, P.; Fung, A.S. The effect of building aspect ratio on energy efficiency: A case study for multi-unit residential buildings in Canada. Buildings 2014, 4, 336-354. [CrossRef]

19. Xu, X.; Feng, G.; Chi, D.; Liu, M.; Dou, B. Optimization of performance parameter design and energy use prediction for nearly zero energy buildings. Energies 2018, 11, 3252. [CrossRef]

20. Lee, B.; Trcka, M.; Hensen, J.L.M. Building energy simulation and optimization: A case study of industrial halls with varying process loads and occupancy patterns. Build. Simul. 2014, 7, 229-236. [CrossRef] 
21. Gourlis, G.; Kovacic, I. Passive measures for preventing summer overheating in industrial buildings under consideration of varying manufacturing process loads. Energy 2017, 137, 1175-1185. [CrossRef]

22. Gourlis, G.; Kovacic, I. A study on building performance analysis for energy retrofit of existing industrial facilities. Appl. Energy 2016, 184, 1389-1399. [CrossRef]

23. Brinks, P.; Kornadt, O.; Oly, R. Development of concepts for cost-optimal nearly zero-energy buildings for the industrial steel building sector. Appl. Energy 2016, 173, 343-354. [CrossRef]

24. Chow, W.K.; Chan, K.T. Parameterization study of the overall thermal-transfer value equation for buildings. Appl. Energy 1995, 50, 247-268. [CrossRef]

25. Yu, J.; Tian, L.; Yang, C.; Xu, X.; Wang, J. Sensitivity analysis of energy performance for high-rise residential envelope in hot summer and cold winter zone of China. Energy Build. 2013, 64, 264-274. [CrossRef]

26. Heiselberg, P.; Brohus, H.; Hesselholt, A.; Rasmussen, H.; Seinre, E.; Thomas, S. Application of sensitivity analysis in design of sustainable buildings. Renew. Energy 2009, 34, 2030-2036. [CrossRef]

27. German Federal Institute for Occupational Safety and Health, Technical Rule for Workplaces ASR A3.5. 2010. Available online: www.baua.de/de/Themen-von-A-Z/Arbeitsstaetten/ASR/ASR-A3-5.html (accessed on 5 December 2020).

28. Trade Union Congress. The Case for A Legally Enforceable Maximum Temperature. 2009. Available online: www.tuc.org.uk/sites/default/files/extras/maxtemp2009.pdf (accessed on 5 December 2020).

29. GBZ1-2010. Hygienic Standards for the Design of Industrial Enterprises; People's Medical Publishing House: Beijing, China, 2010.

30. Kjellstrom, T.; Lucas, R.; Lemke, B.; Sahu, S. Occupational heat effects: A global health and economic threat due to climate change. In Climate Change and Global Health; CAB International: Wallingford, UK, 2014.

31. EnergyPlus. Available online: energyplus.net (accessed on 30 September 2020).

32. Li, J.; Meng, X.; Wei, B.; Wang, Y.; Xu, Y. Analysis on thermal performance of industrial buildings envelope. J. HV AC 2019, 49, 67-70.

33. GB 50176-2016. Code for Thermal Design of Civil Building; China Architecture and Building Press: Beijing, China, 2016.

34. Zhao, H. Indoor Heat Convection and Ventilation; China Architecture and Building Press: Beijing, China, 2009.

35. GB 50019-2015. Design Code for Heating Ventilation and Air Conditioning of Industrial Buildings; China Planning Press: Beijing, China, 2015.

36. Zhao, R. Air Conditioning; China Architecture and Building Press: Beijing, China, 2009.

37. China Meteorological Bureau, Climate Information Center; Climate Data Office and Tsinghua University, Department of Building Science and Technology. China Special Meteorological Database for Building Thermal Environment Analysis, 1st ed.; China Architecture and Building Press: Beijing, China, 2005.

38. Švajlenka, J.; Kozlovská, M.; Pošiváková, T. Analysis of selected building constructions used in industrial construction in terms of sustainability benefits. Sustainability 2018, 10, 4394. [CrossRef]

39. Švajlenka, J.; Kozlovská, M. Effect of accumulation elements on the energy consumption of wood constructions. Energy Build. 2019, 198, 160-169. [CrossRef]

40. Stefania, D.G.; Mariangela, D.V.; Pierluigi, D.B.; Luis, P.; Alessandra, R. Designing the sustainable adaptive reuse of industrial heritage to enhance the local context. Sustainability 2020, 12, 9059.

Publisher's Note: MDPI stays neutral with regard to jurisdictional claims in published maps and institutional affiliations.

(C) 2020 by the authors. Licensee MDPI, Basel, Switzerland. This article is an open access article distributed under the terms and conditions of the Creative Commons Attribution (CC BY) license (http://creativecommons.org/licenses/by/4.0/). 